\section{Comentario a dos escritos}

Leí el comentario del profesor Juan Carlos Eslava (COMENTARIO. Una nueva oportunidad para confrontar con otros ojos el pasado. Biomédica 2005;25:304) sobre el artículo del doctor Álvaro Javier Idrovo (Reseña histórica. Posibles efectos en la salud asociados con la metalurgia precolombina. Biomédica 2005; 25:295-303).

Comparto el comentario del profesor Eslava y también estoy de acuerdo con el cuando dice, sobre Biomédica, que la revista tiene "el prestigio de haberse interesado, desde siempre, por entender la complejidad de los fenómenos asociados con la enfermedad humana". Quiero aprovechar la oportunidad para proponer a los responsables de Biomédica que se acentúe ese perfil de ella, con el propósito de hacer del mismo algo que se convierta en identificador de la publicación, sobre todo en esta nueva época de estar en el índice de Pubmed y poderse acceder a sus textos completos en forma libre, desde cualquier lugar del mundo. Lo que yo quiero resaltar específicamente del comentario del profesor Eslava es su estímulo para que la Revista publique artículos polémicos, y mientras más lo sean mejor, agrego yo, como éste del doctor Idrovo, cuya "osada implicación, en el marco que ofrece el documento, es un acicate para el intelecto y puede servir para habilitar una interesante discusión sobre la validez del modelo de transición", que ha obnubilado por completo el pensamiento de quienes estudian la cosa demográficaepidemiológica, convirtiendo ese modelo en una teoría con claros intereses políticos, que se disfrazan con ropajes y máscaras académicocientíficas.

Esa es mi invitación: que Biomédica promueva la publicación de escritos polémicos, con elevado rigor académico, de tal manera que ese estilo se convierta en un sano y envidiable identificador de la publicación.

\section{Jaime Carmona-Fonseca}

Grupo Malaria, Universidad de Antioquia

jaimecarmonaf@hotmail.com

\title{
* * *
}

\section{Comentario a la Nota Técnica "Determinación de la permeabilidad viral de los condones de membrana de poliolefina al bacteriófago $\Phi \times 174$ "}

Desde el punto de vista riesgo-beneficio, el usar un condón con una eficacia del $93 \%$ para prevenir una enfermedad como el sida, el riesgo es alto. Yo creo que ninguno de los autores se monta en un avión que tiene un 7\% de probabilidades de caerse. Recordemos que el sida es mortal.

Cuando "condonizamos" la salud pública estamos convirtiendo a los usuarios en individuos sin dominio de sí, en animales no racionales, y a las mujeres como mero objeto de placer.

Pablo Arango Restrepo

Director, Departamento de Bioética, Facultad de Medicina,Universidad de La Sabana,

Bogotá, D. C., Colombia.

\section{Respuesta}

Con la "Determinación de la permeabilidad viral de los condones de membrana de poliolefina al bacteriófago $\Phi \times 174 "$ no se pretende hacer una defensa a ultranza del uso de este preservativo, sino que se aporta conocimiento científico a la decisión de emplearlo como método de barrera en la transmisión de las infecciones de tipo sexual.

Además, se entiende que dentro de las políticas en salud pública se desarrollan acciones de promoción que incluyen programas de educación sexual, los cuales apuntan al uso racional de la sexualidad, a la consolidación de parejas estables y no a la promiscuidad.

Por otra parte, el Ministerio de la Protección Social viene desarrollando el plan de respuesta intersectorial, en el cual se pone de manifiesto que el condón no es un fin por sí mismo, sino un 
medio para prevenir las infecciones de transmisión sexual; por lo tanto, las personas que trabajan en salud pública deberían promover el uso del condón dentro de condiciones de respeto, responsabilidad, compromiso y amor, teniendo en cuenta que ningún método de prevención es 100\% eficaz.

\section{Oscar Eugenio Sierra Ospina}

Instituto de Ciencias Básicas, Facultad de Medicina, Universidad Colegio Mayor de Nuestra

Señora del Rosario

Bogotá D. C., Colombia.

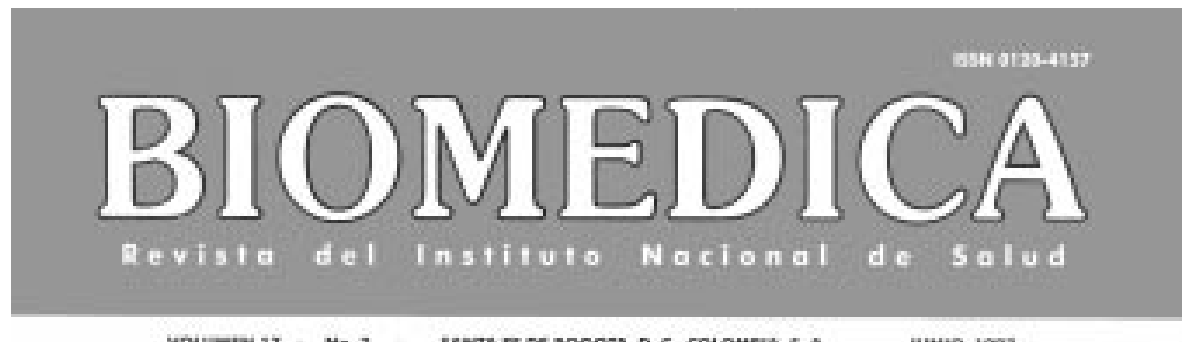

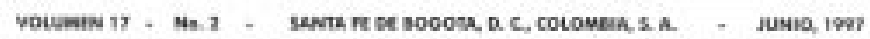

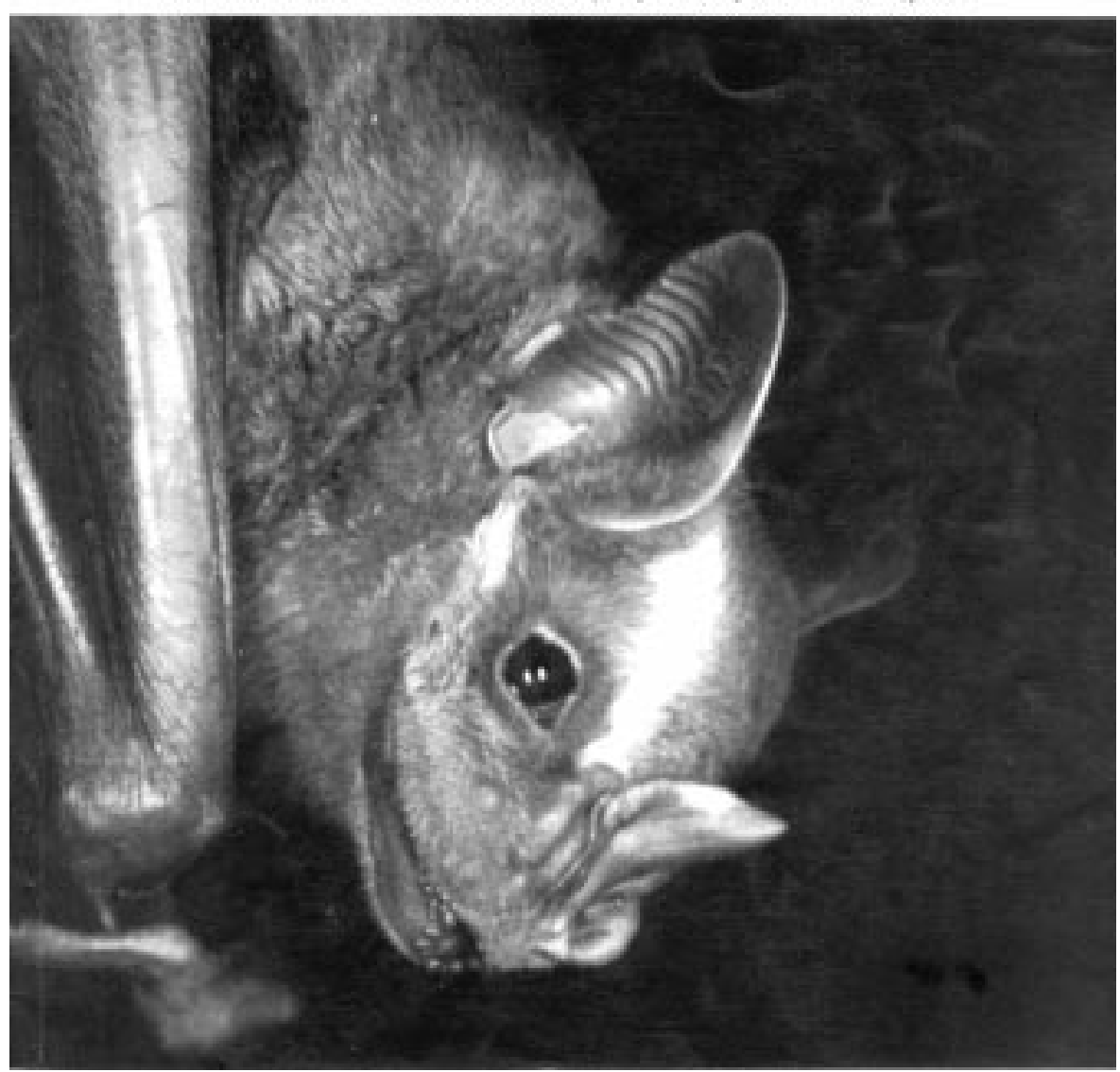

